\title{
DCHS2 Gene
}

National Cancer Institute

\section{Source}

National Cancer Institute. DCHS2 Gene. NCI Thesaurus. Code C125170.

This gene is involved in calcium-dependent cell adhesion. 